\title{
An unexpected record of an African mangrove crab, Perisesarma alberti Rathbun, 1921, (Decapoda: Brachyura: Sesarmidae) in European waters
}

\author{
Jean-Philippe Pezy ${ }^{1 *}$, Adnan Shahdadi ${ }^{2,3}$, Alexandrine Baffreau' ${ }^{1}$, Cedric d'Udekem d'Acoz ${ }^{4}$, \\ Christoph D. Schubart ${ }^{2}$ and Jean-Claude Dauvin ${ }^{1}$
}

\begin{abstract}
Background: Finding of a single female specimen of the African mangrove crab Perisesarma alberti Rathbun, Bull Am Mus Nat Hist 43: 379-474, 1921, in the intertidal zone of the eastern part of the Bay of Seine, English Channel, France.

Result: Identification and description of the recorded crab, photographs and measurements of the single specimen. Comparison with reports from West African mangroves.

Conclusion: It is unlikely to assume an African origin of the collected species. It is more likely a species escaped from an aqua-terrarium, even if the common species in the French aquarium trade have an Australasian origin.
\end{abstract}

Keywords: New European record, Aquarium trade, Eastern tropical Atlantic, English Channel

\section{Background}

Aquarium releases are one of the five top avenues for introduction of non-native species (Ruiz et al., 1997). The accidental release of the tropical alga Caulerpa taxifolia (M.Vahl) C.Agardh, 1817 into the Mediterranean Sea from the tropical aquaria at the Oceanographic Museum of Monaco in 1984 and its subsequent rapid proliferation (Meinesz and Hesse, 1991), is one of the most dramatic examples. In France, 14 genera of tropical true crabs and one genus of tropical hermit crabs are selling in garden or pet shops. Among these species, for France, there is only one species belonging to the family Sesarmidae: Pseudosesarma moeschii (De Man, 1892) (often spelled as Pseudosesarma moeshi), a species also sold under the names of Sesarma bidens [(= Perisesarma bidens (De Haan, 1835)] or Sesarma mederi [(= Episesarma mederi (Milne Edwards, 1853)]. New French regulations on the import and marketing of tropical exotic species, inspired by

\footnotetext{
* Correspondence: jean-philippe.pezy@unicaen.fr

${ }^{1}$ Normandie Univ, UNICAEN, UNIROUEN, Laboratoire Morphodynamique Continentale et Côtière, UMR CNRS 6143, 24, rue des Tilleuls, F-14000 Caen, France

Full list of author information is available at the end of the article
}

the Washington and Berne conventions, require increasingly that sold species cannot survive in local ecosystems (August, 10th 2004 Order modified by July, 30th 2010 Order). So far, no tropical marine fish, alga, crustacean, and/or corals marketed species has been reported along the Atlantic coast to the English Channel. Actually, 18 exotic decapods are presently observed along the French Atlantic coastline (Goulletquer, 2016). Several Non-Native-Species (NNS), decapods can be introduced as an adult stage (e.g. Callinectes sapidus Rathbun, 1896 according to Amanieu \& Le Dantec, 1961) on vessels' sea-chests (Coutts \& Dodgshun, 2007) or as early life stages in ballast water, such as the Hemigrapsus genus, Hemigrapsus sanguineus (De Haan, 1835) and Hemigrapsus takanoi Asakura \& Watanabe, 2005 which present a large population extension along the French coast of the English Channel (Gothland et al., 2013).

\section{Methods}

During the 2016 summer survey in the framework of the NNS inventory in Normandy, the coasts were investigated during low tide in different intertidal habitats to 
find diverse NNS. Along the coast of Normandy, from the Mount-Saint-Michel Bay to the Bay of Somme, 27 sites have been visited in spring and regularly prospected. In July and August 2016, some supplementary sites in the intertidal zone of the Bay of Seine and in Le Havre harbour were investigated to discover new presences of non-native species. On 14 August 2016, at the site of Cricqueboeuf (Fig. 1), one unknown crab was caught in the upper part of the intertidal zone in the region of freshwater influences of the Seine estuary (coordinates: latitude 49.406273; longitude 0.144799), where the summer salinity is $30-32$. The crab was found under a boulder, the substratum consisted of peat lands with a freshwater source seeping from the top of the foreshore (Fig. 2). The other crab species encountered were Hemigrapsus sanguineus (De Haan, 1835), H. takanoi Asakura \& Watanabe, 2005, and Carcinus maenas (Linnaeus, 1758). The crabs were collected and preserved in formaldehyde solution for further investigations. The Perisesarma crab have been identified by Adnan Shahdadi who did his $\mathrm{PhD}$ thesis on "Molecular phylogeny, phylogeography and taxonomic revision of species of the genera Perisesarma and Parasesarma (Decapoda: Brachyura: Sesarmidae)" at the Universität Regensburg in Germany.

\section{Results}

In the laboratory, the unknown crab was identified as a member of the family Sesarmidae Dana, 1851, the genus
Perisesarma De Man, 1895, and the species Perisesarma alberti (Rathbun, 1921).

\section{Taxonomic history and citations}

Sesarma (Chiromantes) alberti Rathbun, 1921: 448.

Sesarma (Chiromantes) alberti Capart, 1951: 189.

Sesarma (Chiromantes) alberti Monod, 1956: 440.

Sesarma (Perisesarma) alberti Manning \& Holthuis, 1981: 245.

Perisesarma alberti Ng et al., 2008: 222.

Material examined: one female, maximum carapace width $21.0 \mathrm{~mm}$, maximum carapace length $18.4 \mathrm{~mm}$, Cricqueboeuf, at the mouth of the Seine estuary, eastern part of the English Channel, Normandy, France, the 14 August 2016 (Figs. 1 and 3).

The specimen was later integrated in the crustacean collection of the National Museum of Natural History at Paris, under the collection number MNHN-IU-2016-1499.

Diagnosis: Carapace subrectangular, slightly broader than long (carapace width/carapace length $=1.14$ ), front moderately deflexed, with broad, relatively deep, median concavity, post-frontal lobes prominent, median lobes slightly broader than lateral ones, separated by deep furrow, dorsal carapace regions moderately well indicated, anterolateral margin with sharp exorbital angle and two epibranchial teeth, anterior one well developed, and the second one distinct, but less pronounced. Upper surface of chelar palm with one oblique pectinated crest with

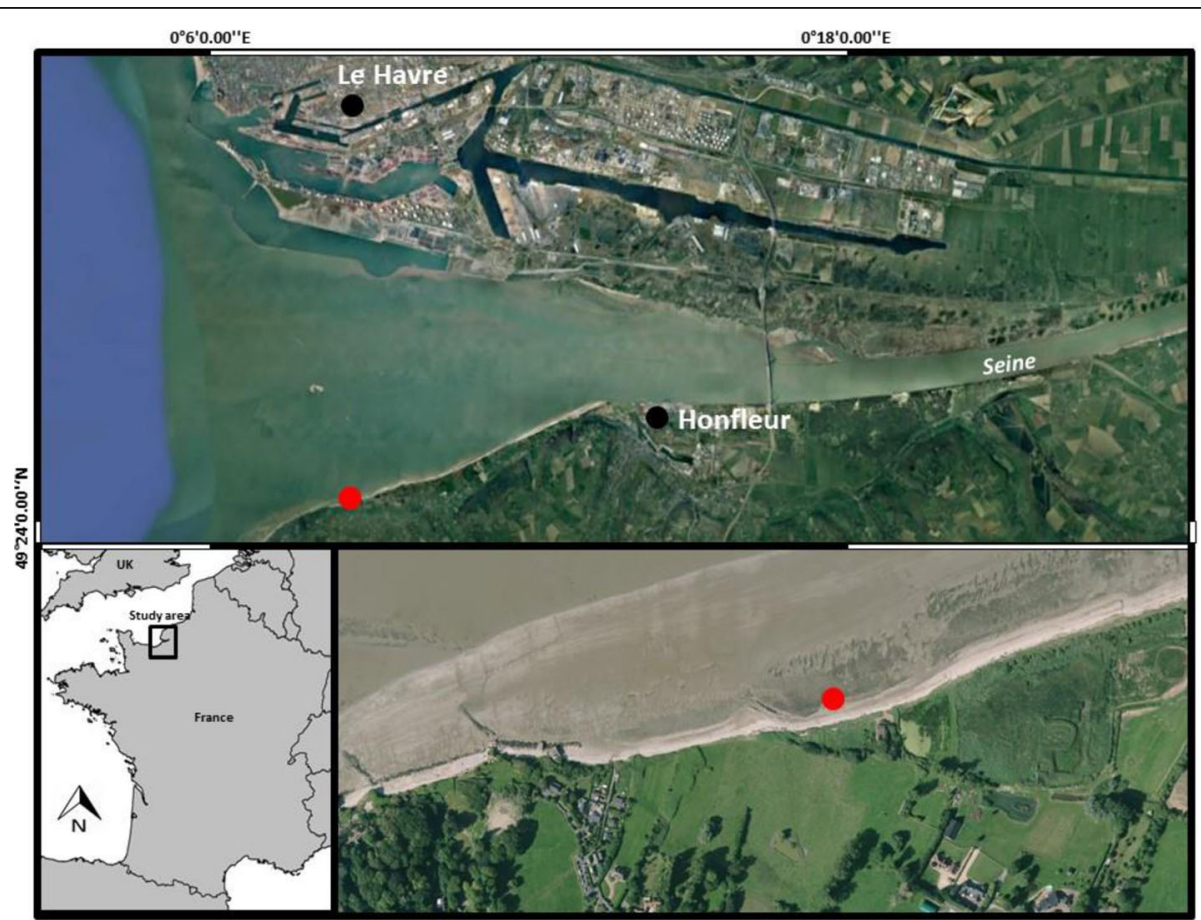

Fig. 1 Locality of collection of single Perisesarma alberti female at the site of Cricqueboeuf (in red), at the mouth of the Seine Estuary, eastern part of the English Channel 




Fig. 2 Sampling site of Perisesarma alberti (scale bar: $0.3 \mathrm{~m}$ )

short teeth; chelar dactylus with 30 low and transversely elongated tubercles on the dorsal surface. Ambulatory legs relatively short and broad. Pleon broad, evenly rounded. Gonopore positioned in the depression on anterior edge of sternite 5, slightly touching the posterior margin of sternite 4, with an elongated operculum almost parallel to sternal sutures and a small sternal cover on the anterolateral corner of the operculum (Fig. 3).

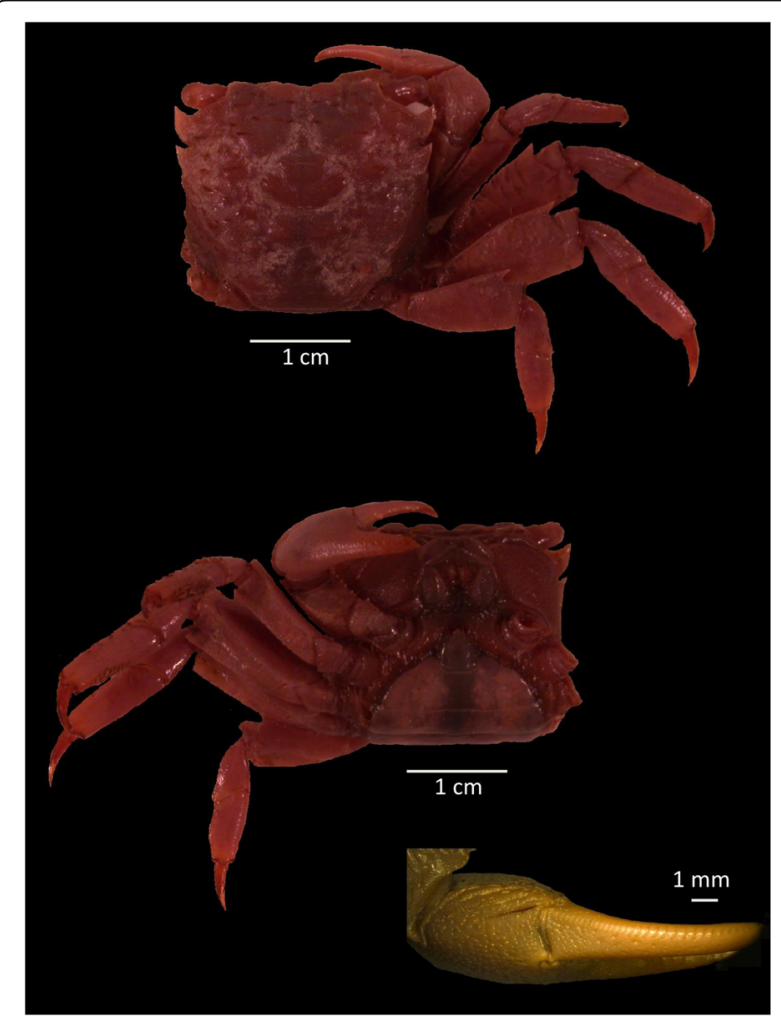

Fig. 3 Photographs of the specimen of Perisesarma alberti. Dorsal and ventral view; right chela. Left appendages broken after fixation

\section{Discussion}

The record of Perisesarma alberti in Normandy is unexpected. It is a strictly tropical species, of which the northern limit of distribution is Guinea (Manning \& Holthuis 1981), and a range extension to France can be excluded. As a West African mangrove species, it is also a potential candidate for accidental transport north by rafting or transport on the hull of ships. Larval transport in ballast water could not be excluded, but development to adult hood on the French shores seems very unlikely or impossible (even in summer time) because of the low temperatures $\left(<20^{\circ} \mathrm{C}\right)$ and inappropriate habitat. The proximity of Le Havre harbour is also a probable source of this exotic introduction; in this site, numerous marine species have been observed for the first time in France or Europe (Breton, 2014; Pezy et al., 2017). It is not impossible that a commercial ship from East-Africa could transport through sea-chest this specimen observed near Le Havre Harbour.

Another hypothesis could be a release from an aquaterrarium. However, this is not a species offered for sale in the official aquarium trade in France, which is focused on a few Australasian species (e.g. http://www.floraquatic.com/197-crabes-d-eau-douce and https://www.universaquatique.fr/775-crabes-d-eau-douce [accessed 23 Feb. 2017]). In spite of French Regulation, considering the French Environmental Code and the 2016 Law on Biodiversity (several decrees already published, e.g., Decree 2017-595 April 2017), and a national strategy addressing the issue of invasive exotic species published in December 2016 by the French Ministry of Environment, it is possible that an escape or a voluntary release on the seashore from an aqua-terrarium could thus hold by a hobbyist with access to specialized sources of supply or a private collector. Furthermore the species is not one of the most aesthetically attractive crab species.

In conclusion, the origin of transport of the specimen remains mysterious. 
This record is very accidental, but even in the case of a repeated introduction, this would most likely remain without impact on the native fauna and flora, as Perisesarma alberti is a strictly tropical crab, unlikely to support the cool climate of Normandy and cold winters.

\section{Conclusion}

It is unlikely to assume an African origin of the collected species. It is more likely a species escaped from an aquaterrarium, even if the common species in the French aquarium trade have an Australasian origin.

\section{Funding}

This study is involved in the REGENI project financed by the AESN (Agence de l'Eau Seine Normandie, France).

\section{Availability of data and materials}

The specimen is part of the collection of non-native species recorded in Normandy and is listed under the number MNHN-IU-2016-1499 in the Paris National Museum of Natural History.

\section{Authors' contributions}

JPP sampled the crab, did the map and began the redaction. AB did the bibliography in link to the REGENI project and modified the photos. CUA and AS identified the genus and the species. AS took photo and wrote the diagnosis. JCD and CDS and all the co-authors commented and participated to the final redaction of the paper. All authors read and approved the final manuscript.

\section{Ethics approval and consent to participate}

There are no ethical considerations.

\section{Consent for publication}

There are no need authorizations to publish.

\section{Competing interests}

The authors declare that they have no competing interests.

\section{Publisher's Note}

Springer Nature remains neutral with regard to jurisdictional claims in published maps and institutional affiliations.

\section{Author details}

${ }^{1}$ Normandie Univ, UNICAEN, UNIROUEN, Laboratoire Morphodynamique Continentale et Côtière, UMR CNRS 6143, 24, rue des Tilleuls, F-14000 Caen, France. ${ }^{2}$ Zoologie \& Evolutions biologie, Universität Regensburg, D-93040 Regensburg, Germany. ${ }^{3}$ Department of Biology, Faculty of Science, University of Hormozgan, Bandarabbas, Iran. ${ }^{4}$ Royal Belgian Institute of Natural Sciences, rue vautier 29, B-1000 Brussels, Belgium.

Received: 21 March 2017 Accepted: 14 December 2017

Published online: 29 December 2017

\section{References}

Agardh C. Synopsis algarum Scandinaviae, adjecta dispositione universali algarum, 1817, pp. [i]-xl, [1]-135. Lundae [Lund]: Ex officina Berlingiana.

Amanieu M, Le Dantec J. Sur la présence accidentelle de Callinectes sapidus M. Rathbun à l'embouchure de la Gironde. Revue des Travaux de l'Institut des pêches Martimes. 1961;25(3):339-49.

Asakura A, Watanabe S. Hemigrapsus takanoi, new species, a sibling species of the common Japanese intertidal crab H. penicillatus (Decapoda : Brachyura: Grapsoidea). J Crustac Biol. 2005;25:279-92.

Breton G. Espèces introduites ou invasives des ports du Havre, d'Antifer et de Rouen (Normandie, France). Hydroécologie Appliquées. 2014;18:23-65.

Capart A. Crustacés décapodes brachyures. Expédition océanographique Belge dans les eaux côtières africaines de l'Atlantique Sud (1948-1949). Résultats Scientifiques. 1951;3(1):1-205.
Coutts ADM, Dodgshun TJ. The nature and extent of organisms in vessel sea-chests: a protected mechanism for marine bioinvasions. Mar Pollut Bull. 2007;54(7):875-86.

Dana JD. Crustacea Grapsoidea (Cyclometopa, Edwardsii). Conspectus Crustaceorum quae in Orbis Terrarum circumnavigatione, Carolo Wilkes e Classe Reipublicae Foederatae duce, lexit et descripsit J.D. Dana. Proc Acad Natl Sci Phila. 1851;5:247-54.

de Haan W. Crustacea. in P. F. de Siebold, Fauna Japonica sive descriptio animalium, quae in itinere per Japoniam, jussu et auspiciis superiorum, qui summum in India Batava Imperium tentent, suscepto, annis 1823-1830 collegit, notis, observationibus et adumbrationibus illustra. Leiden, 1835: I-XVII, I-XXXI, 1-244, pl. 1-55, A-Q.

De Man JG. Decapoden des Indischen Archipels. Zool Ergebnisse Einer Reise in Niederländisch Ost-Indien. 1892;2:265-527.

De Man JG. Bericht über die von Herrn Schiffscapitän Storm zu Atjeh, an den westlichen Küsten von Malakka, Borneo und Celebes sowie in der Java-See gesammelten Decapoden und Stomatopoden. Zool Jahrb Abt Syst Geographie und Biologie der Thiere. 1895-1898;9:75-218.

Gothland M, Dauvin JC, Denis L, Jobert S, Ovaert J, Pezy JP, Spilmont N. Additional records and current distribution (2012) of Hemigrapsus sanguineus (de Haan, 1835) along the French coast of the English Channel. Manag Biol Invasions. 2013:4:305-15.

Goulletquer P. Guide des organisms exotiques marins. France: Editions Belin; 2016. 303 p.

Linnaeus C. Tomus 1. Systema naturae per regna trianaturea, secundum classes, ordines, genera, species, cum characteribus, differentiis, synonymis, locis. Editio decimal, reformata. Holmiae. (LaurentiiSalvii), 1758:[1-4], 1-824.

Manning RB, Holthuis LB. West African brachyuran crabs (Crustacea: Decapoda). Smithson Contr Zool. 1981;306:1-379.

Meinesz A, Hesse B. Introduction et invasion de l'algue tropicale Caulerpa taxifolia en Méditerranée nord-occidentale. Oceanol Acta. 1991;14:415-26.

Milne Edwards H. Memoire sur la Famille des Ocypodiens, suite (1). Annls Sci Nat (Zoologie). 1853;20:163-228.

Monod T. Hippidea et Brachyura ouest-africains. Mémoires de I'Institut Français d'Afrique Noire. 1956:45:1-674.

Ng P.K.L., Guinot D. and Davie P.J.F. (2008) Systema Brachyurorum: part I. An annotated checklist of extant brachyuran crabs of the world. Raffles Bulletin of Zoology. Supplement 17, 1-286.

Pezy JP, Baffreau A, Dauvin JC. Records of two introduced Penaeidae (Crustacea: Decapoda) species from Le Havre harbour, France, English Channel. Biolnvasions Records. 2017;6 in press

Rathbun MJ. The genus Callinectes. Proc US Nat Mus. 1896;18:349-75.

Rathbun MJ. The brachyuran crabs collected by the American museum Congo expedition 1905- 1915. Bull Am Mus Nat Hist. 1921;43:379-474.

Ruiz G, Carlton J, Grosholz E, Hines H. Global invasions of marine and estuarine habitats by non-indigenous species: mechanisms, extent and consequences. Am Zool. 1997:37:621-32

Submit your next manuscript to BioMed Central and we will help you at every step:

- We accept pre-submission inquiries

- Our selector tool helps you to find the most relevant journal

- We provide round the clock customer support

- Convenient online submission

- Thorough peer review

- Inclusion in PubMed and all major indexing services

- Maximum visibility for your research

Submit your manuscript at www.biomedcentral.com/submit
Biomed Central 